\title{
Effect of silver nanoparticles, spermine, salicylic acid and essential oils on vase life of Alstroemeria
}

\author{
Motahareh Ershad Langroudi ${ }^{1}$, Davood Hashemabadi ${ }^{2}$, Sepideh Kalatejari $^{1}$, Leila Asadpour ${ }^{2}$ \\ ${ }^{1}$ Islamic Azad University, Science and Research Branch, Faculty of Agriculture and Food Science, Department of Horticultural \\ Science and Agronomy, Tehran, Iran.E-mail: mt_ershad@yahoo.com, kalatehjari@srbiau.ac.ir \\ ${ }^{2}$ Islamic Azad University, Rasht Branch, Faculty of Science Rasht, Department of Science, Rasht, Iran. E-mail: \\ hashemabadid@yahoo.com, 1.asadpour@yahoo.com
}

Received: 30/12/2017; Accepted: 13/02/2019.

\begin{abstract}
In this study, effects of different concentrations of silver nanoparticles (NS), salicylic acid (SA), spermine (SP), dill $(\mathrm{AN})$, and cumin $(\mathrm{CM})$ essential oils were investigated on physiological and microbiological traits of alstroemeria (Alstroemeria hybrida) cut flowers during a preharvest and postharvest application. The study was performed as a factorial experiment based on a randomized completely design with three replications. During the experiment the vase life of cut flower was evaluated in terms of chlorophylls a, b and total, superoxide dismutase (SOD), lipid peroxidation (MDA), stem and bacterial colonies and bacterial identification. The results showed that using high concentrations of nanosilver (NS2) increased significantly the vase life of cut Alstroemeria in preharvest and postharvest. 11 colonies of bacteria were identified in stem end of cut alstroemeria flowers.
\end{abstract}

Keywords: Alstroemeria hybrida, Essential oils, Silver nanoparticles, Vase life.

Efeito de nanopartículas de prata, espermina, ácido salicílico e óleos essenciais na vida de vaso de Alstroemeria

\section{RESUMO}

Neste estudo, os efeitos de diferentes concentrações de nanopartículas de prata (NS), ácido salicílico (SA), espermina (SP), óleos essenciais de endro (AN) e cominhos (CM) foram investigados nas características fisiológicas e microbiológicas das flores de corte de alstroemeria (Alstroemeria hybrida) durante a pré-colheita e pós-colheita. O estudo foi conduzido num delineamento experimental inteiramente casualizado, no esquema fatorial, com três repetições. Durante o experimento, a vida de vaso da flor de corte foi avaliada em termos de clorofilas a, b e total, superóxido dismutase (SOD), peroxidação lipídica (MDA), colônias bacterianas e identificação bacteriana. Os resultados mostraram que o uso de altas concentrações de nanossilver (NS2) aumentou significativamente a vida de vaso de Alstroemeria em pré e pós-colheita. 11 colônias de bactérias foram identificadas em flores de corte de alstroemeria.

Palavras-chave: Alstroemeria hybrida, óleos essenciais, nanopartículas de prata, vida vaso. 


\section{Introduction}

Alstroemeria (Alstroemeria hybrida) as an important and popular herbaceous cut flower, belongs to Alstroemeriaceae family considering the variations in its color and cold resistance. The main problem of alstroemeria is the short life of its leaves (Ferrante et al., 2004). Postharvest chemical treatments are used to reduce leaf yellowing and extend its vase life. The presence of a sugar in the vase solution effectively delays petal wilting and abscission and prolongs the longevity of many cut flowers. The exogenous sugars provide substrates for respiration and structural support and improve water balance in cut flowers (Pun and Ichimura, 2003).

Senescence of cut flowers may depend on many factors such as water stress, carbohydrate depletion, microorganisms and ethylene effects (Mohd Rafdi et al., 2018). By adding some chemicals to the preservation solutions and provide suitable conditions for the flowers it is possible to delay the quality degradation during postharvest (Ebrahim-Zadeh and SaifiI, 1999).

This study examines the effects of different concentration of nanosilver, salicylic acid, spermine and some essential oils preharvest and postharvest on improving the vase life and maintaining life quality of alstroemeria cut flowers. Salicylic acid could be considered as an endogenous plant hormone involved in the regulation of plant growth, development and disease resistance mechanisms (Hayat et al., 2010; Luo et al., 2011).

Polyamines are a new group of plant growth regulators wherein spermine and spermidine seem to be more effective in preventing senescence-related events than similar treatments (Harindra Champa et al., 2015).
Herbal essential oils are natural compounds that are known as secondary metabolites with a strong effect on pathogens control and a proven antimicrobial impact. Since these compounds increase the vase life of cut flowers, their use is becoming widespread recently (Sharififar et al., 2007; Svircev et al., 2007). The aim of this study is to identify the best treatments and methods on vase life of cut astroemeria flowers.

\section{Material and Methods}

This experiment was carried out in April 2016 on alstroemeria cut flowers obtained from local commercial greenhouse Mahallat located in the Markazi Province in Iran (longitude 50 $49^{\prime} \mathrm{E}$ and latitude $33^{\circ} 87^{\prime} \mathrm{N}$ ) and is $1747 \mathrm{~m}$ above sea level. Plants were grown under standard greenhouse conditions at $22^{\circ} \mathrm{C}$ and $16^{\circ} \mathrm{C}$ day and night temperatures, respectively. Some of the plants were sprayed (approximately $500 \mathrm{ml}$ per plant) with different chemical compounds while the control flowers were sprayed with distilled water. About three weeks later, cut flowers followed by all plants were harvested in the early morning and transported with appropriate cover (in plastic packages) immediately to the laboratory of Horticulture Department. All flowers were uniformly recut with a height of $50 \mathrm{~cm}$ and put in the prepared solutions (Table 1) after removing the leaves at their end of stem and weighting. Vase life was defined as the time from the start of treatment until the senescence of flowers. The vase life of cut flowers was evaluated in a $12 \mathrm{~h}$ photoperiod, the light intensity of $12 \mu \mathrm{mol} \mathrm{m} \mathrm{m}^{-2} \mathrm{~s}^{-1}$, relative humidity of 60 to $70 \%$, and the temperature of $20 \pm 2{ }^{\circ} \mathrm{C}$.

Table 1. Treatments, concentrations and their application methods studied on vase life and post-harvest physiological characteristics of cut alstroemeria flowers.

\begin{tabular}{lllll}
\hline \multirow{2}{*}{ Treatments } & Method & Post-harvest, & $\begin{array}{l}\text { Post-harvest, } \\
\text { continuous }\end{array}$ \\
\hline \multirow{2}{*}{ Nano silver } & NS1 & 5 & 5 & 1 \\
Palicylic acid & NS2 & 10 & 10 & 3 \\
Spermine & SA1 & 200 & 200 & 30 \\
& SA2 & 300 & 300 & 50 \\
Essential oil of dill & SP1 & 10 & 10 & 5 \\
& SP2 & 20 & 20 & 10 \\
Essential oil of cumin & AN1 & 50 & 50 & 5 \\
& AN2 & 100 & 100 & 10 \\
& CM1 & 50 & 50 & 5 \\
& CM2 & 100 & 100 & 10 \\
\hline
\end{tabular}

Numbers inside the table represent the concentration corresponding to each method-treatment level (ppm). 
An aqueous solution of NS (5 and 10ppm), SA (200 and 300ppm), SP (10 and 20ppm), AN (50 and $100 \mathrm{ppm}), \mathrm{CM}$ (50 and100ppm) and distilled water were sprayed to run-off (approximately $500 \mathrm{~mL}$ per plant) about three weeks before flowers harvest. Next, both treated (sprayed) and untreated cut flowers were harvested. The cut flowers treated preharvest (B) were kept in vase solution containing sucrose $3 \%$ with distilled water. Vase solution concentrations (pulsing 24h: A1) were distilled water with $20 \%$ sucrose. Vase solution concentrations (continuous: A2) were NS (1 and $3 \mathrm{ppm}), \mathrm{SA}$ ( 30 and $50 \mathrm{ppm}$ ), SP (5 and $10 \mathrm{ppm}$ ), $\mathrm{AN}$ (5 and $10 \mathrm{ppm}$ ), CM (5 and $10 \mathrm{ppm}$ ), and distilled water with $3 \%$ sucrose.

Vase life of the cut flowers was evaluated daily. The period from the first day ( 0 day) when cut flowers were placed in vase solutions until they lost their ornamental value were measured. The end of alstroemeria vase life was determined with yellowing of $50 \%$ leaves or falling $50 \%$ florets (Ferrante et al., 2004).

In order to measure $\mathrm{a}, \mathrm{b}$, and total chlorophyll content of the plants, sampling was performed in the first and last days of the test. The process of measuring chlorophyll was performed using Mazumdar and Majumder (2003) method and finally, the leaf chlorophyll content was suggested in $\mathrm{mg} \mathrm{g}^{-1}$ of fresh weight. The difference between the amount of chlorophyll of first and last days represents the degradation of chlorophyll, which is calculated using the following formula:

Chlorophyll a $=9.93\left(\mathrm{~A}_{660}\right)-0.777\left(\mathrm{~A}_{642.5}\right)$

Chlorophyll $\mathrm{b}=17.6\left(\mathrm{~A}_{642.5}\right)-2.81\left(\mathrm{~A}_{660}\right)$

Total Chlorophyll = $7.12\left(\mathrm{~A}_{660}\right)-16.8\left(\mathrm{~A}_{642.5}\right)$

Degradation of Chlorophyll a, $\mathrm{b}$, total $=$ Chlorophyll $\mathrm{a}, \mathrm{b}$, and total (first day) - Chlorophyll a, b, and total (last day). SOD activity in petals of cut alstroemeria was measured at $1^{\text {st }}, 4^{\text {th }}, 8^{\text {th }}$, and $12^{\text {th }}$ days based on the spectrophotometry by Giannopolitis and Ries (1977) method on petal tissue. The reaction solution $(1 \mathrm{~mL})$ contained $50 \mathrm{mM}$ phosphate buffer $(\mathrm{pH}=7), 12 \mathrm{mM}$ riboflavin, $13 \mathrm{mM}$ methionine, $0.1 \mathrm{mM}$ EDTA, $7 \mathrm{mM}$ nitro blue tetrazolium (NBT), and $10 \mu \mathrm{L}$ of extracted enzyme solution. A solution with no enzyme was used as the control. Test tubes were irradiated under fluorescent lights at $100 \mathrm{mmol} \mathrm{m}{ }^{-2} \mathrm{~s}^{-1}$ for $20 \mathrm{~min}$. The absorbance of each solution was measured at $560 \mathrm{~nm}$ using a spectrophotometer. One unit of enzyme activity was defined as the amount of enzyme that would inhibit $50 \%$ of NBT photo reduction.

For measuring Lipid peroxidation (MDA), a branch was removed at the end of vase life of the control and its petals were measured as peroxidation reaction product of membrane fatty acids to determine peroxidation of lipids and lipid peroxidation (MDA) using Heath and Packer's method (1968).
To estimate bacterial population in stems after treatments, $2-\mathrm{cm}$ length (approximately $0.5 \mathrm{~g}$ ) segments were cut from the stem ends. Explants were washed three times with sterile distilled water to reduce surface microbial loads. The explants were then ground and diluted with $0.9 \%$ sterile herbal saline. Aliquots $(0.1$ $\mathrm{mL}$ ) of extract were spread on nutrient agar plates, and bacterial colonies were enumerated after incubation for $24 \mathrm{~h}$ at $37^{\circ} \mathrm{C}$. All bacteria counts were conducted on triplicate sub-samples (Balestra et al., 2005). After plate counting, obtained colonies were studied and separated by their apparent morphological differences. As a result, 11 bacterial isolates were obtained that were purified and differentiated according to their typical morphological and biochemical characteristics.

Bacterial morphological studies were motility, cell shape, and capsule presence. The biochemical tests carried out on isolated bacterial colonies were Gram reaction using $\mathrm{KOH}$, aerobic/anaerobic growth, acid production from glucose, gas production from Dglucose, fluorescent pigments production on $\mathrm{KB}$, oxidase test, catalase test, gelatin hydrolysis, starch hydrolysis, urease, indole production, methyl red reaction, acetoin (VP), nitrate reduction, and $\mathrm{H}_{2} \mathrm{~S}$ production from cysteine (Janse, 2005).

Data were subjected to analysis of variance (ANOVA) in SAS statistical software. Sources of variation were different concentrations of treatments and methods. The mean values were compared by the Least Significant Difference (LSD) test at the 0.05 and 0.01 of probability level.

\section{Results and Discussion}

The results of analysis of variance vase life of cut Alstroemeria hybrida flowers showed that the effect of interaction of treatments $(\mathrm{T})$ in different methods $(\mathrm{M})$ on the vase life of alstroemeria was significant at $1 \%$ level so that there was a significant difference at $1 \%$ level between chemical treatments at all levels and preservative methods (Table 2).

In general, the maximum vase life of alstroemeria was related to the interaction effect of silver nanoparticles treatment with a concentration of $10 \mathrm{ppm}$ (NS2) and the pre-harvest methods (B) with an average of 23 days. Furthermore, the minimum vase life of alstroemeria was related to the interaction effect of the DW treatment (distilled water and sucrose 20\%) and the pulse method (A1) with an average of 11.33 days (Figure 1).

The results are in accordance with the findings of (Liu et al., 2009) that are the positive impact of silver nanoparticles at a concentration of $5 \mathrm{ppm}$ on the vase life of gerbera cut flower. In another study, it was reported that a concentration of $1.5 \mathrm{mM}$ salicylic acid 
had increased the vase life of cut gladiolus flower from 18 days for the control group to 21 days (Jalili Marandi et al., 2011).The use of any of treatments of spermine and herbal essential oils increased vase life and vase life compared to the control that these results correspond with the results of other research in this area (Lee et al., 1997; Zhang et al., 2003). Many studies indicated that nanosilver increase quality and vase life of cut flowers such as gerbera (Solgi et al., 2009) and lilium (Kim et al., 2005).

Basiri et al. (2011) showed that nanosilver could extend the vase life of cut carnation. NS particles are commonly used in a range of fields for its antimicrobial properties, including the medical industry and for vegetable disinfestations (Jiang et al., 2004). These effects have been confirmed by Liu et al. (2009) who reported that NS could profoundly inhibit bacterial growth in vase solutions, as well as at plant stem ends, which concomitantly results in the extended vase life of the flowers. Jin et al. (2006) demonstrated that salicylic acid improved flower tolerance to water deficit stress and increased vase life of cut rose flowers. Spermine has a well-established role in the stimulation of cell division and in the delay of senescence. Besides, it is known for its anti-senescence effects during an aging sequence of plant tissues (Kitada et al., 1979).Variance analysis of the data shows that the amount of chlorophyll a, b, and the total is statistically significant at $1 \%$ level of likelihood. As shown in (Table 2 and Figures 2, 3, 4) application of preharvest nanosilver treatment $(10 \mathrm{ppm})$ is found to be more effective in a decrease in chlorophyll degradation. Among the studied treatments, nanosilver (NS2) and control (DW) treatments had respectively the highest and lowest chlorophyll contents during an experiment in all methods.

Table 2. Analysis of variance for different parameters of Alstroemeria hybrida

\begin{tabular}{lccccccccc}
\hline & & \multicolumn{7}{c}{ Means of squares } \\
\cline { 3 - 10 } $\begin{array}{l}\text { Source of } \\
\text { variations }\end{array}$ & df & VL & Chl. a & Chl. b & Chl. t & MDA1 & MDA4 & MDA8 & MDA12 \\
\hline Treatment (T) & 10 & $43.26^{* *}$ & $0.815^{* *}$ & $0.400^{* *}$ & $0.274^{* *}$ & $16.12^{*}$ & $383.3^{* *}$ & $1210^{* *}$ & $2271^{* *}$ \\
Method (M) & 2 & $47.03^{* *}$ & $0.404^{* *}$ & $0.192^{* *}$ & $0.210^{* *}$ & $24.37^{*}$ & $1016^{* *}$ & $3905^{* *}$ & $5341^{* *}$ \\
$\mathrm{~T} \times \mathrm{M}$ & 20 & $1.141^{* *}$ & $0.018^{*}$ & $0.0009^{*}$ & $0.0012^{* *}$ & $19.64^{*}$ & $53.87^{*}$ & $49.79^{*}$ & $19.28^{* *}$ \\
Error & 66 & 0.434 & 0.0085 & 0.00045 & 0.00029 & 6.6 & 13.56 & 9.65 & 6.68 \\
$\mathrm{CV}(\%)$ & & $43.26^{* *}$ & $0.815^{* *}$ & $0.400^{* *}$ & $0.274^{* *}$ & 9.47 & 9.13 & 5.34 & 3.11 \\
\hline
\end{tabular}

${ }^{*}, * *$ : Significant at the 0.05 and 0.01 probability level, respectively, ${ }^{\text {ns }}$ : Not significant at $\mathrm{p}=0.05$.

VL: Vase life, Ch. a: degradation of Chlorophyll a, Ch. b: degradation of Chlorophyll b, Ch. t: degradation of total Chlorophyll, MDA1: MDA (first day), MDA4: MDA ( $4^{\text {th }}$ day), MDA8: MDA $\left(8^{\text {th }}\right.$ day), MDA12: MDA $\left(12^{\text {th }}\right.$ day).

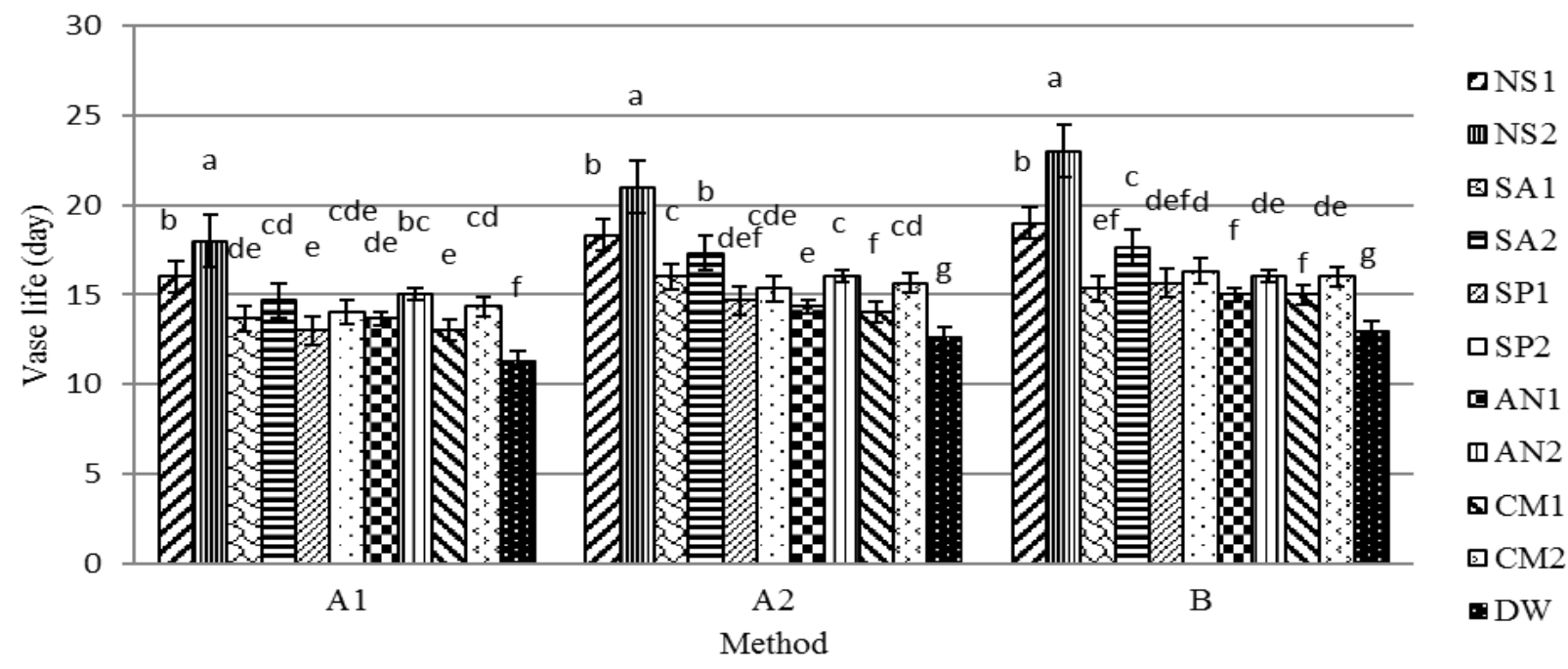

Figure 1. The effect of different treatment-method levels on vase life in Alstroemeria hybrida cut flowers. Methods: (A1: Pulsing 24 h, A2: continuous, B: Pre-harvested) and Treatments: (NS: Nano silver, SA: Salicylic acid, SP: Spermine, AN: Essential oil of dill, CM: Essential oil of Cumin, DW: Control). 


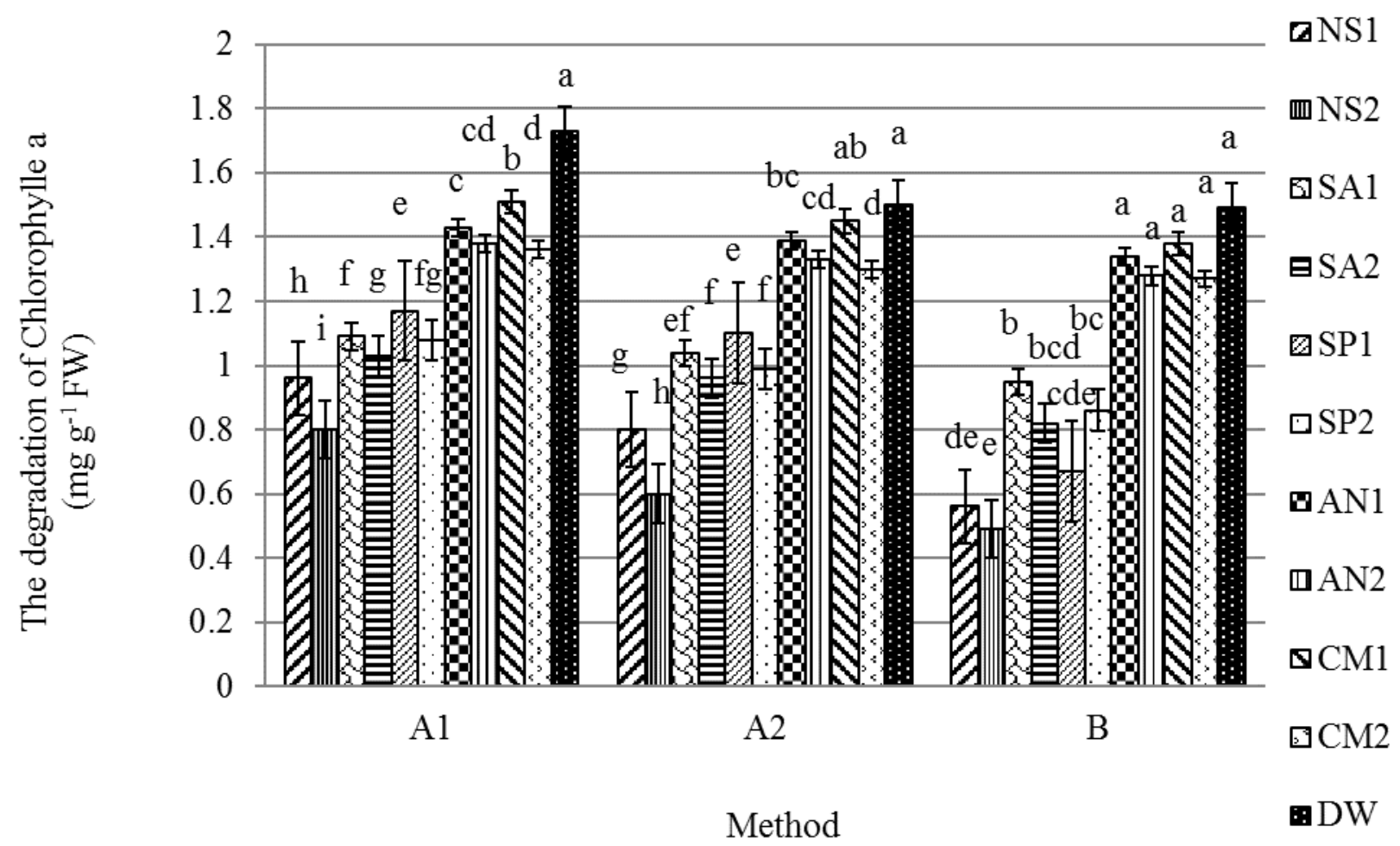

Figure 2. Effect of different treatments on the degradation of Chlorophyll a, of Alstroemeria hybrida.

Methods: (A1: Pulsing 24 h, A2: continuous, B: Pre-harvested) and Treatments: (NS: Nano silver, SA: Salicylic acid, SP: Spermine, AN: Essential oil of dill, CM: Essential oil of Cumin, DW: Control).

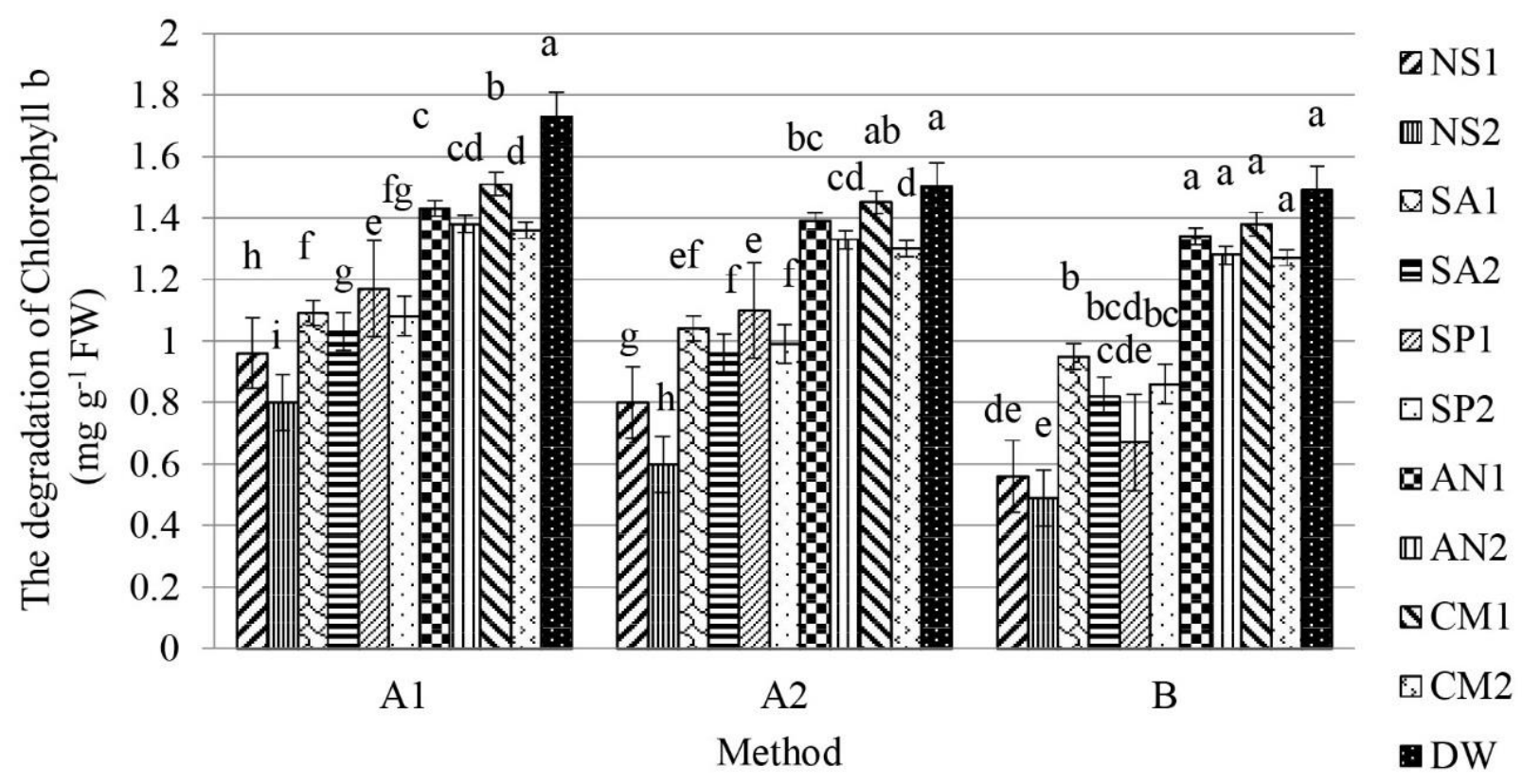

Figure 3. Effect of different treatments on the degradation of Chlorophyll $\mathrm{b}$ of Alstroemeria hybrida.

Methods: (A1: Pulsing 24 h, A2: continuous, B: Pre-harvested) and Treatments: (NS: Nano silver, SA: Salicylic acid, SP: Spermine, AN: Essential oil of dill, CM: Essential oil of Cumin, DW: Control). 


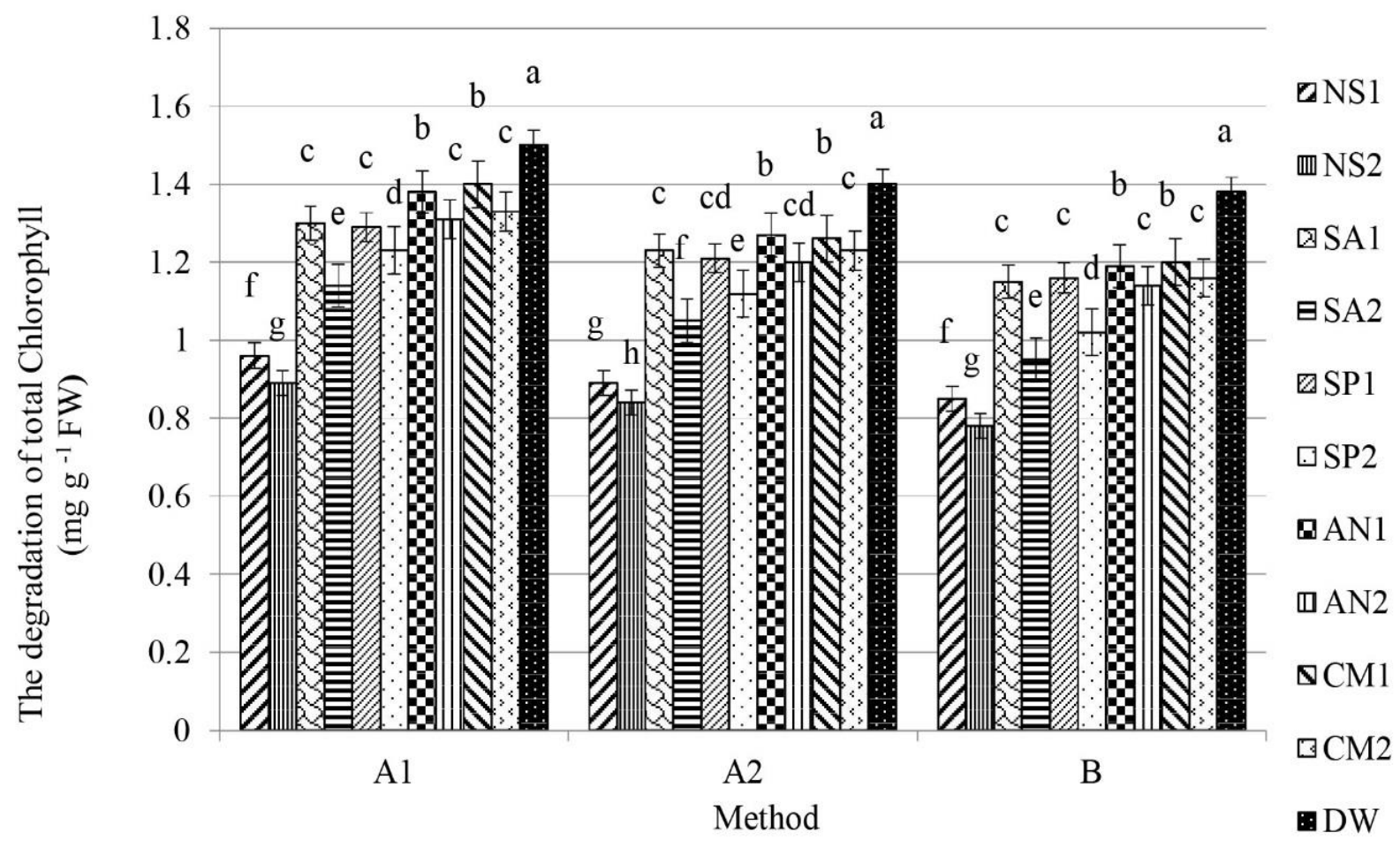

Figure 4. Effect of different treatments on the degradation of total chlorophyll of Alstroemeria hybrida.

Methods: (A1: Pulsing 24 h, A2: continuous, B: Pre-harvested) and Treatments: (NS: Nano silver, SA: Salicylic acid, SP: Spermine, AN: Essential oil of dill, CM: Essential oil of Cumin, DW: Control).

Mousavi Bazaz and Tehranifar (2011) investigated the effects of cumin, mint and thyme extracts (50 and $100 \mathrm{mgl}^{-1}$ ) and ethanol (4 and 7\%) on the vase life of cut alstroemeria (Alstroemeria $\mathrm{sp}$ ) and reported that all treatments were effective on vase life alstroemeria cut flowers.

The decrease in chlorophyll is considered to be a symptom of oxidative stress condition, this decrease after infection might be due to the generation of reactive oxygen species (ROS) causing damage to chlorophyll a, implying the plant's failure to capture the light and thus photosynthesis will be decreased or stopped (Ali and Alqarainy, 2006). This reduction may be because of chlorophyll degradation, reduced chlorophyll synthesis, and stability of thylakoid membrane. In addition, it may be associated with the increased activity of chlorophyllase enzyme (El-Shanhorey et al., 2014). It seems that the above anti-ethylene treatments cause the preservation of Chlorophyll by inhibition of the activity of chlorophyllase enzyme and development of chloroplasts. Yellowing of the leaves is a common phenomenon in many sensitive species such as Astroemeria, Lilium, Chrysanthemum and stock. In many species, leaf yellowing may be caused by placing plants in the dark for a long time during storage or transport (Ferrante et al., 2002). Mousavi Bazaz and Tehranifar (2011) evaluated the effects of herbal essential oils on alstroemeria cut flower and found that the use of these compounds is effective to increase chlorophyll content. In addition, similar results were reported which confirm our findings (Hashemabadi, 2011; Basiri et al., 2011).

The ANOVA test showed that interaction treatments (T) in the methods (M) of the SOD enzyme was significant on cut flowers on different days. The results showed that SOD activity decreased significantly during the experiment. Among all treatments of nanosilver, NS2 had the highest SOD activity and the lowest activity of the SOD enzyme was related to control treatment (DW) at all methods. Overall, the highest amount of SOD enzyme was the application of preharvest nanosilver $(10 \mathrm{ppm})$ with $3 \%$ sucrose on the 12th day with an average of $120 \mu \mathrm{mol} / \mathrm{g} \mathrm{FW}$ and the lowest amount of SOD activity was the application of pulsing (distilled water with $20 \%$ sucrose) with an average of $22.68 \mu \mathrm{mol} / \mathrm{g} \mathrm{FW}$ on the $12^{\text {th }}$ day (Table 3 ).

The ANOVA test results showed that the statistically significant effect of different treatments and methods on content of MDA $(\mathrm{P}<0.05)$. Information obtained by mean comparison revealed that all treatments caused a decrease in MDA accumulation than that of the control (DW). The results of this experiment showed that MDA content increased during vase period. The lowest content of MDA (20 nmol g-1 FW) was observed in the application of pre-harvest (B) nanosilver treatment (10 ppm) with sucrose $3 \%$ on the $12^{\text {th }}$ day. 
Table 3. Analysis of variance for different parameters of Alstroemeria hybrida.

\begin{tabular}{lcccccccc}
\hline & \multicolumn{8}{c}{ Means of squares } \\
\cline { 2 - 8 } $\begin{array}{l}\text { Source of } \\
\text { variations }\end{array}$ & df & SOD1 & SOD4 & SOD8 & SOD12 & Bac1 & Bac2 & Bac6 \\
\hline Treatment (T) & 10 & $181.8^{* *}$ & $1094^{* *}$ & $1252^{* *}$ & $3486^{* *}$ & $0.0058^{* *}$ & $0.291^{* *}$ & $0.822^{* *}$ \\
Method (M) & 2 & $756.6^{* *}$ & $9535^{* *}$ & $10427^{* *}$ & $6006^{* *}$ & $0.0688^{* *}$ & $0.442^{* *}$ & $3.398^{* *}$ \\
T×M & 20 & $69.52^{* *}$ & $74.7^{* *}$ & $105^{* *}$ & $100.5^{* *}$ & $0.0064^{* *}$ & $0.032^{* *}$ & $0.709^{* *}$ \\
Error & 66 & 4.75 & 6.16 & 4.22 & 5.98 & 0.0011 & 0.004 & 0.213 \\
CV (\%) & & 1.28 & 1.802 & 2.03 & 4.16 & 2.313 & 1.183 & 6.39 \\
\hline
\end{tabular}

${ }^{*},{ }^{* *}$ : Significant at the 0.05 and 0.01 probability level, respectively, ${ }^{\text {ns }}$ : Not significant at $\mathrm{p}=0.05$.

SOD1: (first day), SOD4: ( $4^{\text {th }}$ day), SOD8: $\left(8^{\text {th }}\right.$ day), SOD12: (12 ${ }^{\text {th }}$ day), Bac1: Bacterial population end of stem (first day), Bac2: Bacterial population end of stem (2th day), Bac6: Bacterial population end of stem ( $6^{\text {th }}$ day).

On the other hand, the highest content of MDA was observed in the $12^{\text {th }}$ day of DW (distilled water and $20 \%$ sucrose) in pulsing method (A1) with an average of 120 nmol g ${ }^{-1} \mathrm{FW}$ on the plant fresh weight. MDA, a product of lipid peroxidation, has been proposed as a suitable marker of lipid peroxidation (Bailly et al., 1996). Kazemi and Ameri (2012) reported the positive effect of herbal essential oils of thyme and lavender on the stability of the membrane and reduction of MDA in clove cut flowers, which are consistent with the results of the present research. The number of bacteria in stem end of cut flowers decreased significantly with the application of nanosilver treatment. The least number of bacteria was obtained in the stems treated with nanosilver with high concentration preharvest and postharvest. We found that all compounds had antibacterial effects on stem ends microorganisms and could decrease these preservative compounds. The most consistent antibacterial action was found in pretreatment nanosilver (NS2) particles.

Enterobacteriaceae is a large group of gram-negative bacteria identified in the stem end of cut alstroemeria flowers. This group includes E-coli, Enterobacter, Klebsiella, Proteus, Serratia, Citrobacter, and Pseudomonas, as well as a variety of gram-positive bacteria including Staphylococcus Aureus, Streptococcus, Bacillus cereus, and Actinomycetes. Low water uptake by cut flowers is often due to occlusions located mainly in the basal stem end cut flowers (He et al., 2006). Microorganisms and their decay products are a common cause of stem end blockage (Van Doorn, 1997). Basiri et al. (2011) indicated that the lowest bacteria concentration in the stem end of cut carnations was obtained with $5 \mathrm{mg} / \mathrm{l}$ silver nanoparticles and the highest concentration rate was observed in control plants. Hence, nanosilver treatment has antibacterial effects and can extend the quality and vase life of cut flowers. In addition to Bacillus, Van Doorn et al. (1991) found different bacterial strains such as pseudomonads, enterobacteria, and some other genera such as Aeromonas, Acinetobacter, Alcaligenes, Citrobacter and Flavobacterium, which occurred infrequently in rose stems. In another study Van Doorn and De Witte (1997) detected Pseudomonads and Enterobacteria were detected as the dominant bacterial strains in stems of cut 'Sonia' roses.

\section{Conclusions}

This study showed that application of nanosilver (NS2) preharvest plays a high preservative role by prolonging the vase life of alstroemeria cut flowers. Moreover, it was observed that other treatments effectively extend vase life. Thus, the results suggest that nanosilver treatment has the potential to be used commercially to extend the vase life of cut alstroemeria flowers.

\section{Bibliographic References}

Ali, A., Alquarainy, F., 2006. The lutein preventation and treatment for age-related diseases. Journal of Biology science, $8,187-250$.

Bailly, C., Benamar, A., Corbineau, F., Come, D., 1996. Changes in malondialdehyde content and in superoxide dismutase, catalase and glutathione reductase activities in sunflower seeds as related to deterioration during accelerated aging. Physiologia Plantarum, 97, 104-110.

Balestra, G.M., Agostini, R., Bellincontro, A., Mencarelli, F., Varvaro, L., 2005. Bacterial populations related to gerbera (Gerbera jamesonii L.) stem break. Phytopathologia Mediterranea, 44, 291-299. 
Basiri, Y., Zarei, H., Mashayekhi, K., 2011. Effects of nanosilver treatments on vase life of cut flowers of carnation (Dianthus caryophyllus cv. 'White Librity'). Journal of Advanced Laboratory Research in Biology, 2, 49-55.

Ebrahim-Zadeh, A., Saifi, Y., 1999. Storage and handling of cut flowers, potted plants and ornamental greenery, third ed. Akhtar Publications, Tabriz.

El-Shanhorey, N., Salem, M., Mohamed, N., 2014. Effect of salinity and humic acid treatments on growth and chemical composition of Jatropha curcas plants. Bulletin of Faculty of Agriculture, 65, 474-488.

Ferrante, A., Hunter, D.A., Hackett, W.P., Reid. M.S., 2002. Thidiazuron-a potent inhibitor of leaf senescence in Alstroemeria. Postharvest Biology and Technology, 25, 333338.

Ferrante, A., Vernieri, P., Serra, G., Tognoni, F., 2004. Changes in abscisic acid during leaf yellowing of cut stock flowers. Plant growth regulation, 43, 127-134.

Giannopolitis, C.N., Ries, S.K., 1977. Superoxide dismutases I. Occurrence in higher plants. Plant Physiology, 59, 309-314.

Harindra Champa, W.A., Gill, M.I.S., Mahajan, B.V.C., Bedi, S., 2015. Exogenous treatment of spermine to maintain quality and extend postharvest life of table grapes (Vitis vinifera $\mathrm{L}$.) cv. Flame Seedless under low temperature storage. Food Science and Technology, 60, 412-419.

Hashemabadi, D., 2011. Comparison of silver nano-particles and silver thiosulphate on the quality and vase life of cut Carnation flowers cv. 'Tempo'. Final Report of Research Project to Islamic Azad University, Rasht Branch, Iran.

Hayat, Q., Hayat, S., Irfan, M., Ahmd, A., 2010. Effect of exogenous salicylic acid under changing environment. Environmental and experimental botany, 68, 14-25.

He, S., Joyce, D.C., Irving, D.E., Faragher, J.D., 2006. Stem end blockage in cut Grevillea 'Crimson Yul-lo'inflorescences. Postharvest Biology and Technology, 41, 78-84.

Heath, R.L., Packer, L., 1968. Photoperoxidation in isolated chloroplasts: I. Kinetics and stoichiometry of fatty acid peroxidation. Archives of biochemistry and biophysics, 125, 189-198.

Jalili Marandi, A., Hassani, A., Abdollahi, A., Hanafi, S., 2011. Improvement of the vase life of cut gladiolus flowers by essential oils, salicylic acid and silver thiosulfate. Journal of Medicinal Plants Research, 5, 5039-5043.

Janse, J.D., 2005. Phytobacteriology, Principles and Practice, third ed. Wallingford, United Kingdom.

Jiang, H., Manolache, S. Wong, A.C.L., Denes, F.S, 2004. Plasma-enhanced deposition of silver nanoparticles onto polymer and metal surfaces for the generation of antimicrobial characteristics. Journal of Applied Polymer Science, 93, 14111422 .

Jin, J., Shan, N., Ma, N., Bai, J., Gao, J., 2006. Regulation of ascorbate peroxidase at the transcript level is involved in tolerance to postharvest water deficit stress in the cut rose
(Rosa hybrida L.) cv. Samantha. Postharvest biology and technology, 40, 236-243.

Kazemi, M., Ameri, A., 2012. Response of vase-life carnation cut flower to salicylic acid, silver nanoparticles, glutamine and essential oil. Asian Journal of Animal Science, 6, 122-131.

Kim, J.H., Lee, A.K., Suh, J.K., 2005. Effect of certain pretreatment substances of vase life and physiological characters in Lilium spp. Acta Horticulturae, 673, 307-314.

Kitada, M., Igarashi, K., Hirose, S., KIitagawa, H., 1979. Inhibition by polyamines of lipid peroxide formation in rat liver microsomes. Biochemical and Biophysical Research Communications, 87, 388-394.

Lee, M., Lee, S., Park, K., 1997. Effect of spermine on ethylene biosynthesis in cut carnation (Dianthus caryophyllus L.) flowers during senescence. Plant Physiology, 151, 68-73.

Liu, J., He, S., Zhang, Z., Cao, J., Lv, P., Cheng, G., Joyce, D.C., 2009. Nano-silver pulse treatments inhibit stem-end bacteria on cut gerbera cv. Ruikou flowers. Postharvest biology and technology, 54, 59-62.

Luo, Z., Chen, C., Xie, J., 2011. Effect of salicylic acid treatment on alleviating postharvest chilling injury of 'Qingnai' plum fruit. Postharvest biology and technology, 62, 115-120.

Mazumdar, B.C., Majumder, K., 2003. Methods on physcochemical analysis of fruits. College of Agriculture, Calcutta University, India.

Mohd Rafdi, H.H., Joyce, D.C., Irving, D.E., Gantait, S.S., 2018. Citric acid, sucrose and $\mathrm{Cu} 2+$ as potential vase treatments for cut Acacia holosericea G. Don foliage stems. The Journal of Horticultural Science and Biotechnology, 93, 73-80.

Mousavi Bazaz, A.M., Tehranifar, A., 2011. Effect of ethanol, methanol and essential oils as novel agents to improve vaselife of Alstroemeria flowers.Journal of Biological and Environmental Science, 5, 41-46.

Pun, U.K., Ichimura, K., 2003. Role of sugars in senescence and biosynthesis of ethylene in cut flowers. Japan Agricultural Research Quarterly, 37, 219-224.

Sharififar, F., Moshafi, M., Mansouri, S., Khodashenas, M., Khoshnoodi, M., 2007. In vitro evaluation of antibacterial and antioxidant activities of the essential oil and methanol extract of endemic Zataria multiflora Boiss. Food control, 18, 800805.

Solgi, M., KafiI, M.,Taghavi, T.S., Naderi, R., 2009. Essential oils and silver nanoparticles (SNP) as novel agents to extend vase-life of gerbera (Gerbera jamesonii cv.'Dune') flowers. Postharvest biology and technology, 53, 155-158.

Svircev, A.M., Smith, R.J., Zhou, T., Hernadez, M., Liu, W., Chu, C., 2007. Effects of thymol fumigation on survival and ultrastracture of Monilinia fructicola. Postharvest biology and technology, 45, 228-233.

Van Doorn, W., De Stigter, H., De Witte,Y., Boekestein, A., 1991. Micro-organisms at the cut surface and in xylem vessels 
of rose stems, a scanning electron microscope study. Journal of applied bacteriology, 70, 34-39.

Van Doorn, W., De Witte, Y., 1997. Sources of the bacteria involved in vascular occlusion of cut rose flowers. Journal of the American Society for Horticultural Science, 122, 263-266.
Van Doorn, W.G., 1997. Water relations of cut flowers. Horticultural Reviews, 18, 1-8.

Zhang, Y., Chen, K.S., Chen, Q.J., Zhang, S.L., Ren, Y.P., 2003. Effects of acetylsalicylic acid and ethylene treatments on ripening and softening of postharvest kiwifruit. Acta Botanica, 45, 1447-1452. 